\title{
Molecular Dynamics Simulation of Titanium Dioxide Nanoparticle Sintering
}

Vishal N. Koparde and Peter T. Cummings

Department of Chemical Engineering, Vanderbilt University, VU Station B 351604, Nashville, Tennessee 37235 


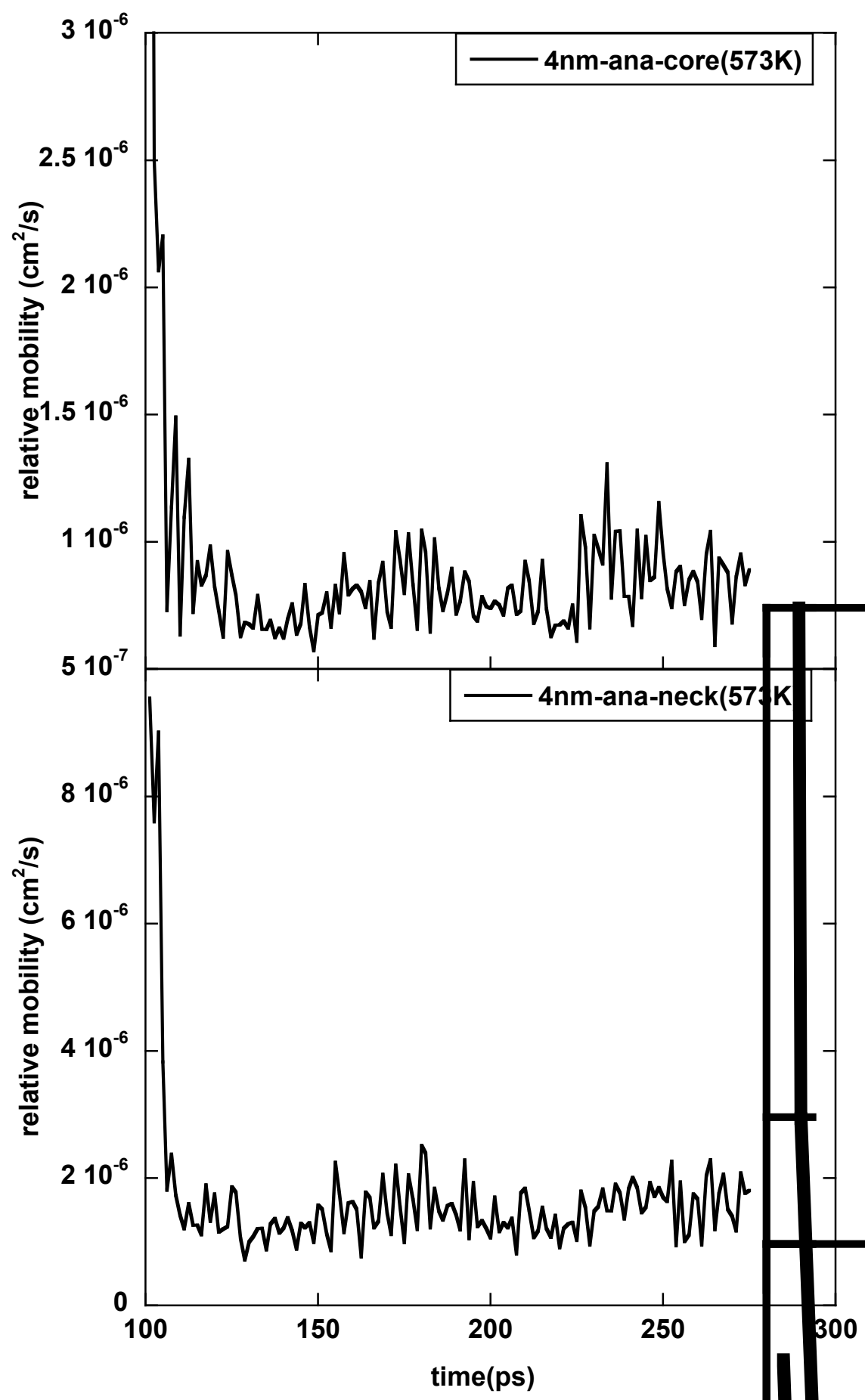

Figure 1S 


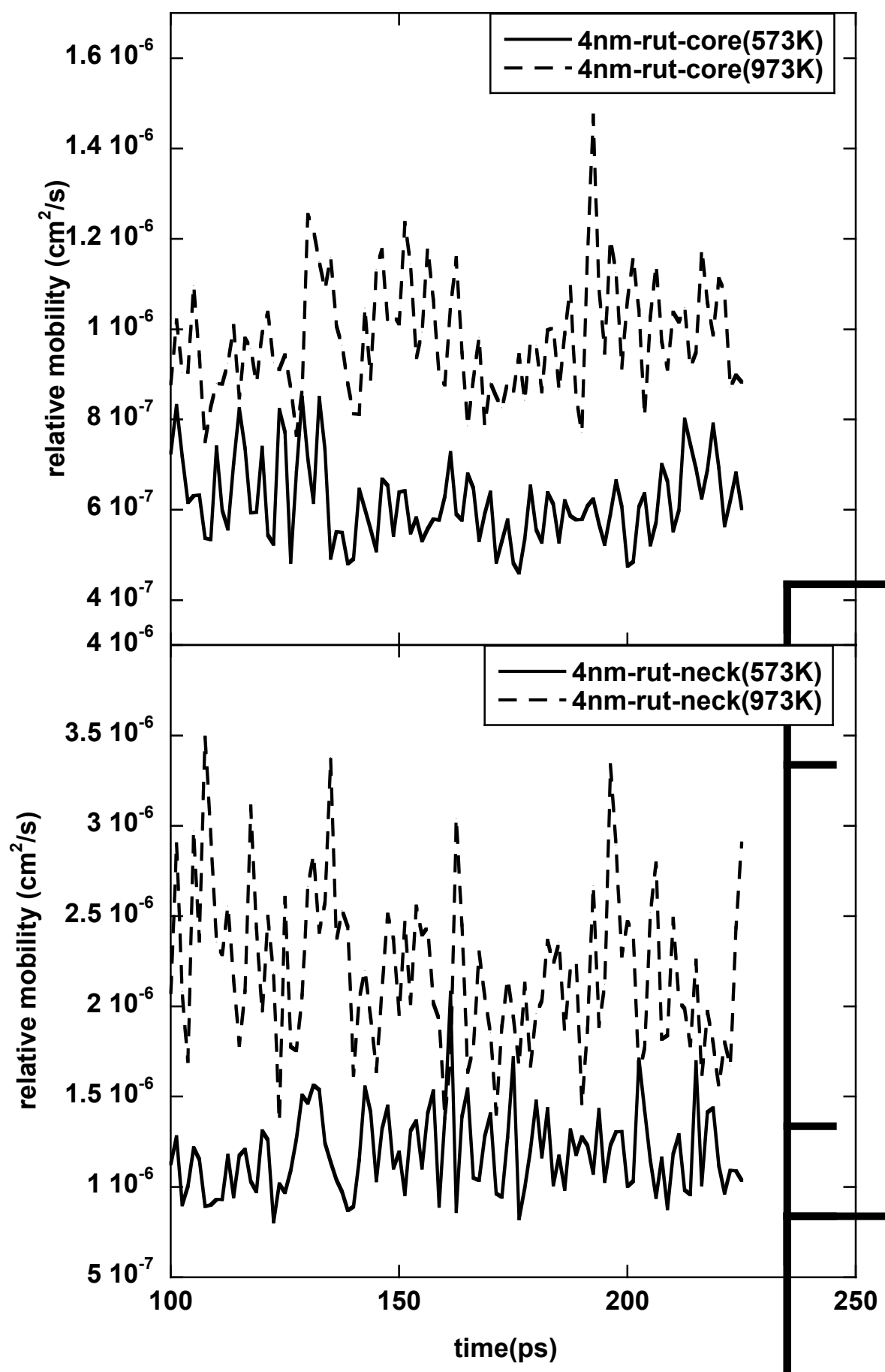

Figure $2 \mathrm{~S}$ 